\title{
PERAN STAKEHOLDER DALAM PENGEMBANGAN \\ DESA WISATA KERTA KECAMATAN PAYANGAN \\ KABUPATEN GIANYAR
}

\author{
Ni Putu Tiya Paristha \\ Universitas Udayana \\ Email: tiyaparistha54@gmail.com \\ I Nyoman Sukma Arida \\ Universitas Udayana \\ Email: sukma_arida@unud.ac.id \\ Gde Indra Bhaskara \\ Universitas Udayana \\ Email: gbhaskara@unud.ac.id
}

\begin{abstract}
Tourism development will be optimal when the potential of an area can be managed properly by stakeholders, by maximizing coordination and integrating their roles and functions to manage their resources. The problems faced by Kerta Tourism Village indicate the weaknesses in its development, therefore efforts are required to improve potential management. One of them is by increasing the contributions through collaboration between stakeholders. This study aims to analyze the role of stakeholders and to formulate a collaborative model in the development of Kerta Tourism Village. The method utilized in this study is a qualitative method with data collection techniques through document analysis, observation, and in-depth interviews with stakeholders that involved in Kerta Village development. The results of this study showed the stakeholders have played their role, yet the involvement of businesses and the media are still relatively low. The collaborative model is formulated by placing the community as the core of development and supported by academics, government, business, and the media as the supporting actors.
\end{abstract}

Keywords: Collaborative Model, Stakeholder, Tourism Village.

\section{Pendahuluan}

Dalam upaya meningkatkan perekonomian masyarakat, Desa Kerta yang merupakan daerah dataran tinggi mengembangkan pariwisata berbasis pedesaan 
melalui pemanfaatan potensi desa yang meliputi potensi pertanian, keindahan alam, aktivitas perdesaan, dan budaya masyarakat agraris sebagai salah satu daya tarik wisata di Kabupaten Gianyar. Dikembangkannya sektor pariwisata tanpa mengesampingkan sektor pertanian merupakan sebuah model potensial untuk meningkatkan kesejahteraan dan kualitas hidup masyarakat di Desa Kerta yang sebagian besar merupakan masyarakat agraris. Dari keberagaman potensi dan adanya dukungan dari masyarakat untuk mengembangkan kegiatan kepariwisataan, Desa Kerta secara resmi ditetapkan menjadi salah satu desa wisata di Kabupaten Gianyar berdasarkan Surat Keputusan Bupati Nomor 429/E-02/HK/2017 bersama dengan delapan desa lainnya, yaitu Desa Kenderan, Kedisan, Taro, Singapadu Kaler, Singapadu Tengah, Kemenuh, Mas, dan Desa Batubulan.

Sebagai sebuah desa wisata, sumber daya dan Desa Kerta masih belum mampu dikembangkan secara optimal. Hal tersebut dikarenakan adanya beberapa kendala yang meliputi lemahnya kualitas sumber daya manusia, keterbatasan fasilitas penunjang pariwisata, serta belum adanya tindakan promosi yang efektif untuk mempromosikan potensi wisata yang dimiliki Desa Kerta, sehingga berpengaruh terhadap jumlah kunjungan wisatawan ke Desa Wisata Kerta. Terkait dengan kendala-kendala tersebut, salah satu upaya yang dilakukan adalah dengan meningkatkan kontribusi melalui kerja sama antar para pemangku kepentingan (stakeholder) terkait. Dengan adanya kerja sama yang terjalin antar stakeholder dapat membantu desa dalam mengatasi permasalahan-permasalahan yang dihadapi serta mempercepat laju pengembangan desa wisata karena setiap stakeholder bekerja sesuai peran dan fungsinya masing-masing.

Hingga saat ini, Desa Kerta telah membangun jejaring kerja sama dengan beberapa pihak, seperti pemerintah daerah, swasta, perguruan tinggi, maupun media. Kerja sama dilakukan sebagai upaya mengoptimalkan pengelolaan potensi desa wisata yang selanjutnya memberikan manfaat terhadap perekonomian lokal dan kesejahteraan masyarakat di Desa Kerta. Berdasarkan hal tersebut, artikel ini 
bertujuan untuk menganalisis peran stakeholder serta merumuskan model kerja sama stakeholder yang sinergis dalam pengembangan Desa Wisata Kerta Kecamatan Payangan Kabupaten Gianyar.

\section{Metode Penelitian}

Teori yang digunakan dalam penelitian ini yaitu teori stakeholder. Teori stakeholder merupakan individu, kelompok atau organisasi baik secara keseluruhan maupun parsial yang memiliki hubungan serta kepentingan terhadap perusahaan (Budimanta, 2008). Adanya stakeholder pada suatu pembangunan wisata tentu akan mengakibatkan terjadinya kolaborasi antar aktor yang terlibat demi mencapai suatu tujuan dan menyukseskan pembangunan kepariwisataan. Salah satu pendekatan yang diusung oleh kementerian pariwisata Indonesia dikenal dengan model pentahelix yang meliputi akademisi, pemerintah, komunitas, bisnis, dan media. Menurut Soemaryani (2016) menyebutkan bahwa, konsep pentahelix merupakan referensi dalam mengembangkan sinergi antara instansi terkait dalam rangka mencapai suatu tujuan. Konsep pentahelix dikenal dapat mempercepat pengembangan potensi pariwisata khususnya dalam pengembangan desa wisata di Indonesia (Novianti, 2020). Dalam konteks pengembangan desa wisata, teori stakeholder digunakan untuk melihat peran yang dijalankan oleh masing-masing pemangku kepentingan pariwisata.

Penelitian ini menggunakan pendekatan kualitatif yang dilakukan di Desa Kerta, Kecamatan Payangan, Kabupaten Gianyar dengan melakukan observasi langsung dan wawancara secara mendalam dengan stakeholder yang terlibat dalam pengembangan pariwisata di Desa Wisata Kerta, diantaranya Dinas Pariwisata Kabupaten Gianyar, Badan Perencanaan Pembangunan Daerah Kabupaten Gianyar, Kepala Desa Kerta, Ketua Badan Permusyawaratan Desa Kerta Ketua Kelompok Sadar Wisata Desa Kerta, Tokoh Adat, unsur akademisi, unsur swasta dan unsur media terkait. Selain itu pengumpulan data juga diperoleh melalui studi dokumen 
dengan menggunakan buku, dokumen, hasil penelitian sebelumnya, serta jurnal yang relevan atau terkait dengan permasalahan yang diteliti. Informan ditentukan dengan menggunakan teknik purposive sampling. Informan dalam penelitian ini terdiri dari lima orang dari unsur pemerintah, lima orang dari unsur masyarakat, tiga orang dari unsur akademisi, dua orang dari unsur bisnis, serta satu orang dari unsur media. Teknik analisis data dilakukan secara deskriptif kualitatif, yaitu menarasikan data yang diperoleh melalui observasi, wawancara, serta studi dokumen. Selanjutnya untuk hasil analisis data disajikan dengan dua cara meliputi formal dan informal.

\section{Pembahasan}

\section{Gambaran Umum Lokasi Penelitian}

Desa Kerta merupakan salah satu dari sembilan desa yang ada di Kecamatan Payangan Kabupaten Gianyar. Desa ini berada di ujung Utara Kecamatan Payangan dan berada di jalur penghubung antara Kawasan Pariwisata Kintamani dan Kawasan Pariwisata Ubud, sehingga menjadi wilayah yang sangat strategis dalam pengembangan pariwisata kedepannya. Desa Kerta memiliki wilayah seluas 17,14 $\mathrm{km}^{2}$. Secara administratif, Desa Kerta berbatasan dengan Desa Banua Kecamatan Kintamani Kabupaten Bangli di sebelah Utara. Di sebelah Timur berbatasan dengan Desa Taro Kecamatan Tegallalang Kabupaten Gianyar. Di sebelah Selatan berbatasan dengan Desa Puhu Kecamatan Payangan Kabupaten Gianyar. Di sebelah Barat berbatasan dengan Desa Buahan dan Desa Buahan Kaja Kecamatan Payangan Kabupaten Gianyar.

Kegiatan alih fungsi lahan di desa ini masih sangat terkontrol. Berdasarkan profil Desa Kerta Tahun 2020, lahan pertanian produktif yang dimiliki Desa Kerta mencapai 1.000,23 hektar, terdiri dari persawahan seluas 224,88 hektar, tanah kering seluas 628,81 hektar dan areal hutan seluas 146,54 hektar. Dari luasan tersebut, dikembangkan kurang lebih dua puluh tujuh jenis komoditas pertanian. Dari sekian 
banyak komoditas yang dikembangkan, komoditi jeruk merupakan komoditas yang mendominasi desa ini. Secara ekonomi, komoditas tersebut telah mampu meningkatkan pendapatan masyarakat serta mengangkat taraf hidup masyarakat di Desa Kerta, namun kurang stabilnya harga komoditas pertanian, khususnya pada puncak produksi, mengakibatkan terjadinya penurunan harga serta menurunnya permintaan. Rendahnya harga dan permintaan turut berdampak pada menurunnya pendapatan masyarakat. Dengan ditetapkannya Desa Kerta sebagai desa wisata, dapat menjadi salah satu upaya untuk meningkatkan pendapatan masyarakat melalui pemanfaatan produk pertanian, keindahan alam, aktivitas dan budaya masyarakat pedesaan sebagai sebuah daya tarik wisata. Upaya pengembangan tersebut menjadi suatu pilihan yang tepat dengan memanfaatkan kelebihan yang dimiliki oleh Desa Kerta.

\section{Potensi Desa Kerta sebagai Desa Wisata}

Desa Kerta memiliki potensi yang beragam seperti potensi alam, potensi budaya, dan potensi buatan. Desa Kerta memiliki lahan pertanian yang cukup luas dan subur dengan sumber daya alam hayati dan sumber daya pertanian yang cukup beragam, serta ditetapkan sebagai Desa Pusat Pertumbuhan (DPP) di Kawasan Payangan Kabupaten Gianyar. Kegiatan pertanian yang dilakukan relatif baik dan tertata serta telah didukung dengan sarana dan prasarana serta fasilitas penunjang pariwisata, seperti akses jalan, akomodasi dan lain sebagainya.

Konsep Tri Hita Karana yang masih terjaga penerapannya dalam kehidupan masyarakat di Desa Kerta memberikan suatu keunikan tersendiri bagi desa ini. Masyarakat Desa Kerta sangat menghormati adat dan istiadat yang berasal dari peninggalan leluhur serta kehidupan masyarakat yang rukun dengan sesama dan sangat menjaga kelestarian lingkungannya. Lingkungan yang masih terjaga ini menjadikan Desa Kerta sangat baik dikembangkan menjadi destinasi pariwisata alam karena beragam potensi alam yang dimiliki masih lestari seperti, hutan, sungai, 
persawahan dan lainnya. Demikian halnya dengan potensi budaya masa lalu dan yang masih hidup hingga sekarang, meliputi situs sarkofagus, sistem pemerintahan Ulu Apad, tradisi dan adat istiadat Bali Aga, goa dan lainnya. Potensi-potensi tersebut merupakan suatu modal yang bernilai dalam menunjang kepariwisataan di Desa Kerta.

\section{Peran Stakeholder dalam Pengembangan Desa Wisata Kerta}

\section{a. Perguruan Tinggi}

Dalam pengembangan Desa Wisata Kerta, perguruan tinggi berperan sebagai konseptor yaitu memberikan pandangan dan analisis berdasarkan kondisi desa wisata dan juga arahan yang tepat untuk memajukan kepariwisataan melalui berbagai kegiatan penelitian dan pengabdian. Hingga saat ini terdapat empat perguruan tinggi yang terlibat dalam pengembangan kepariwisataan di Desa Kerta, diantaranya adalah Fakultas Pariwisata Universitas Udayana, Universitas Gadjah Mada, Universitas Dwijendra, serta Sekolah Tinggi Manajemen Informatika dan Komputer (STMIK) Primakara.

Fakultas Pariwisata Universitas Udayana memiliki peran signifikan dalam perencanaan Desa Wisata Kerta yang meliputi identifikasi dan pemetaan potensi Desa Kerta sebagai langkah awal rencana pembentukan desa wisata. Hasil dari pemetaan potensi tersebut nantinya menjadi roadmap untuk langkah awal mengembangkan Desa Wisata Kerta. Selain itu, Fakultas Pariwisata juga berperan dalam penyusunan Masterplan pengembangan Desa Wisata Kerta. Desa Wisata Kerta dengan Fakultas Pariwisata Universitas Udayana telah sepakat untuk membangun kerja sama seperti yang dapat dilihat pada Gambar 1. Berdasarkan kesepakatan tersebut, Desa Kerta resmi menjadi desa binaan Fakultas Pariwisata Universitas Udayana dalam hal pengembangan desa wisata. 


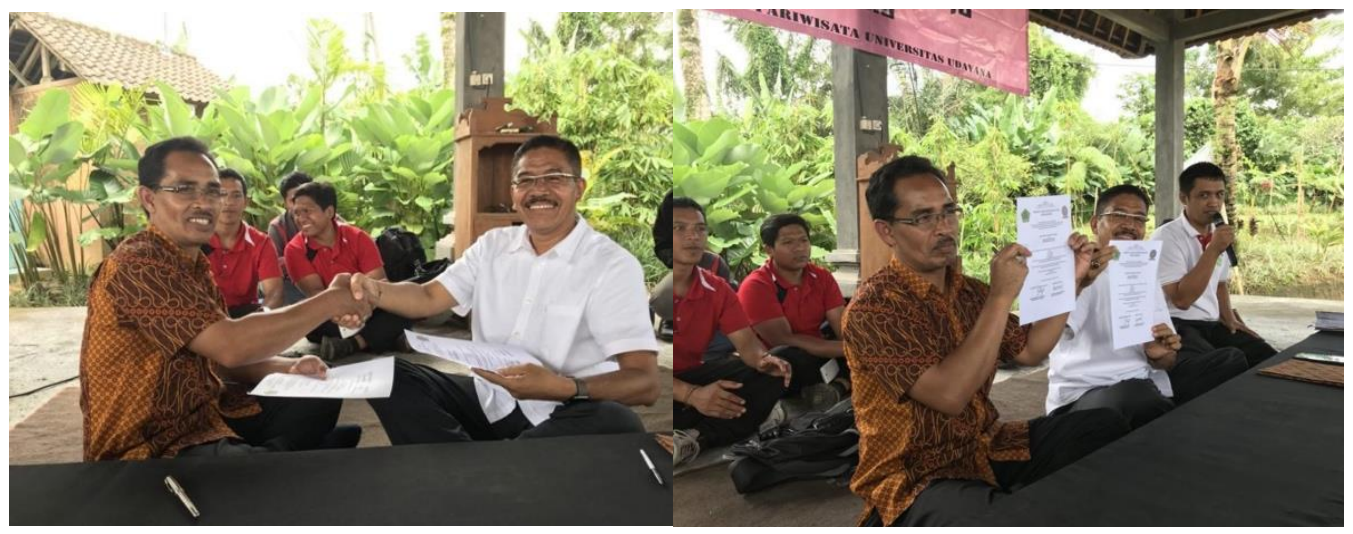

Gambar 1. Penandatanganan Nota Kesepahaman Kerja Sama oleh Kepala Desa Kerta dengan Dekan Fakultas Pariwisata Universitas Udayana Sumber: Website Resmi Desa Kerta, 2018

Selain itu, Universitas Gadjah Mada juga ikut terlibat dalam mendampingi Desa Wisata Kerta melalui kegiatan Kuliah Kerja Nyata Pembelajaran Pemberdayaan Masyarakat (KKN-PPM) yang dilaksanakan di Desa Kerta sejak tahun 2018 hingga saat ini. Dalam pengembangan desa wisata, Universitas Gadjah Mada lebih terfokus pada peningkatan kapasitas dan kualitas sumber daya manusia Desa Kerta sebagai masyarakat yang berkompeten dan mampu terlibat secara aktif dalam pembangunan pariwisata di Desa Kerta. Perguruan tinggi tersebut juga berkontribusi dalam membantu pihak desa dalam melakukan identifikasi potensi desa, membuat brosur dan video profil desa yang selanjutnya dimanfaatkan sebagai video promosi desa wisata, serta melakukan pengadaan infrastruktur seperti pengadaan plang desa wisata serta petunjuk arah jalan menuju masing-masing daya tarik wisata yang ada di Desa Wisata Kerta.

Universitas Dwijendra juga merupakan salah satu mitra kerja sama Desa Wisata Kerta dalam mempersiapkan Desa Kerta sebagai Desa Wisata Ramah Anak. Terkait dengan tindak lanjut program ini, kedepannya Desa Kerta akan menyiapkan kebijakan atau peraturan desa tentang desa ramah anak baik desa dinas maupun masing-masing desa adat di Desa Kerta. Selain itu, seluruh kegiatan kepariwisataan 
di Desa Kerta dipastikan memiliki fasilitas dan infrastruktur yang aman bagi anakanak.

Terakhir, perguruan tinggi STMIK Primakara berperan dalam memberikan pelatihan dalam kegiatan pengabdian masyarakat terkait pembuatan dan pemanfaatan media promosi, seperti website desa, website BUMDes, website penjualan paket wisata, dan pembuatan aplikasi Augmented Reality (AR) dalam rangka digitalisasi desa dan daya tarik wisata yang ada di Desa Kerta. Pelatihan ini merupakan upaya peningkatan promosi desa wisata melalui pemanfaatan teknologi SEO (Search Engine Optimation) yang dimaksudkan untuk mendukung pengembangan potensi wisata dan peningkatan keterlibatan masyarakat di dalam pengelolaan Desa Wisata Kerta.

\section{b. Peran Bisnis}

Unsur bisnis dalam pengembangan Desa Wisata Kerta berperan sebagai enabler yang menyediakan infrastruktur dan fungsi lainnya yang berkaitan dengan pengembangan sumber daya manusia dan pemasaran desa wisata itu sendiri. Terdapat beberapa sektor bisnis yang terlibat dalam pengembangan Desa Wisata Kerta, yaitu CV. Seikou International, The Yogi's Garden Bali dan PT. BUMDes Bersama Gianyar Aman.

Seikou International berperan dalam bidang peningkatan kapasitas sumber daya manusia pariwisata melalui pelatihan-pelatihan bahasa asing dan kewirausahaan bagi pengelola desa wisata dan generasi muda Desa Kerta, serta memberikan pelatihan pemandu wisata (guide) lokal melalui Pokdarwis. Pelatihan tersebut bertujuan untuk menyiapkan sumber daya manusia pariwisata di Desa Kerta menjadi tenaga yang terampil dalam memberikan pelayanan kepada wisatawan. Selain itu, Seikou International juga menjalin kerja sama dalam mempromosikan Desa Wisata Kerta kepada wisatawan, utamanya wisatawan asing yang datang ke Bali dengan mengenalkan produk-produk pertanian maupun potensi lainnya yang ada di 
Desa Wisata Kerta sehingga wisatawan dapat merasakan suasana pedesaan yang sesungguhnya.

Selain itu, PT. Badan Usaha Milik Desa (BUMDes) Bersama Gianyar Aman juga berperan dalam pengembangan Desa Wisata Kerta untuk memasarkan paket wisata seperti yang dapat dilihat pada Gambar 2 sebagai berikut.

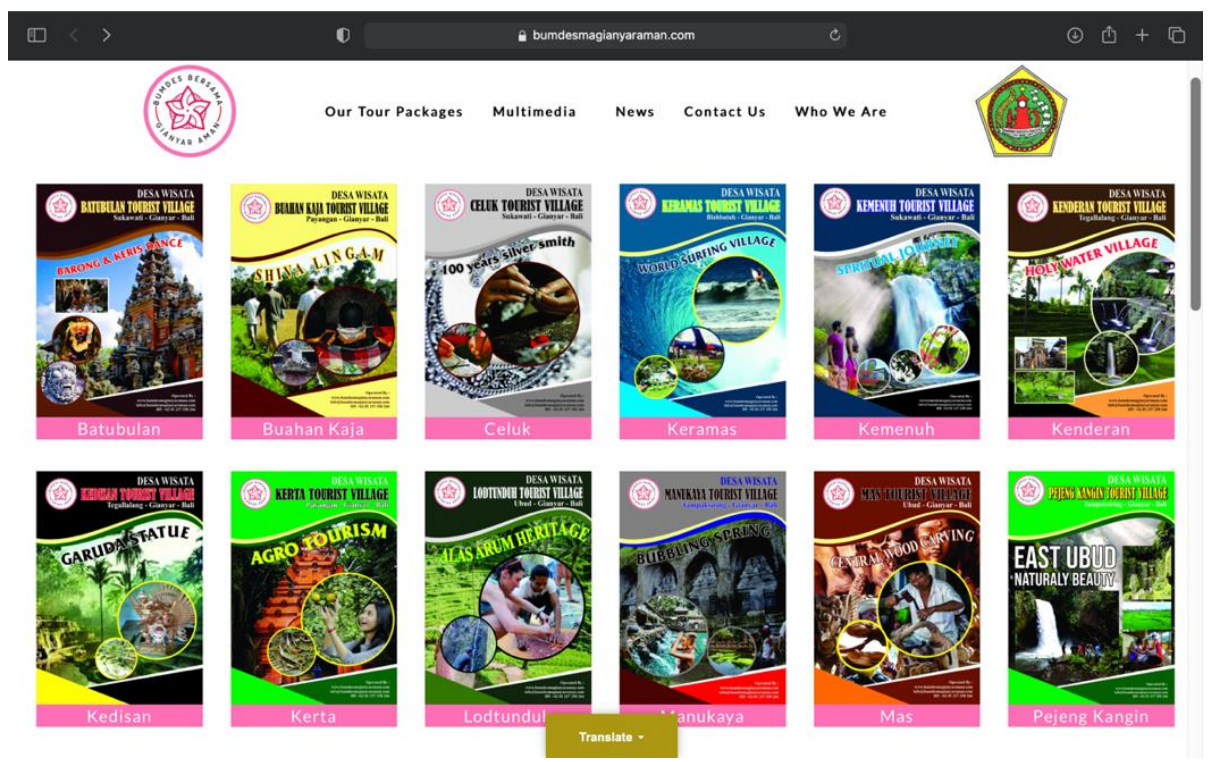

Gambar 2. Pemasaran Paket Wisata melalui BUMDes Bersama Gianyar Aman

Sumber: www.bumdesgianyaraman.com

Berdasarkan Gambar 2, dapat dilihat bahwa desa-desa yang tergabung dalam BUMDes bersama masing-masing membuat paket wisata yang akan ditawarkan kepada wisatawan, selanjutnya akan dipasarkan melalui internet oleh pihak Toorhop dan dikelola langsung oleh BUMDes Bersama Gianyar Aman. Desa Kerta merupakan salah satu desa yang tergabung dalam BUMDes tersebut. Tujuan dari dibentuknya BUMDes bersama ini adalah untuk menghindari kesenjangan dalam perkembangan pariwisata di Kabupaten Gianyar, sehingga diwujudkan melalui kerja sama antar desa, salah satunya dengan mengembangkan BUMDes bersama.

Selanjutnya, The Yogi's Garden Bali memiliki peranan dalam menyediakan barang dan jasa pariwisata di Desa Wisata Kerta, yaitu berupa studio yoga baik untuk private maupun beregu. Selain studio yoga, The Yogi's Garden Bali juga menyediakan 
tempat dimana pengunjung dapat memperoleh ketenangan atau biasa disebut dengan retreat. Tempat ini dilengkapi dengan sarana akomodasi dan suasana alam pedesaan yang masih alami, restoran, serta sebuah perkebunan.

\section{c. Peran Komunitas}

Dalam pengembangan Desa Wisata Kerta, komunitas yang terlibat yaitu pihak desa adat yang memiliki peranan strategis dalam menyediakan lahan milik adat untuk dikelola menjadi daya tarik wisata di Desa Kerta yaitu Bumi Perkemahan Pucak Sari yang merupakan salah satu produk unggulan yang ditawarkan kepada wisatawan di Desa Wisata Kerta. Bumi perkemahan merupakan hasil kerja sama Desa Dinas dengan Desa Adat Pilan. Lahan tersebut merupakan lahan milik Desa Adat Pilan yang mulai dikelola menjadi daya tarik wisata bumi perkemahan pada tahun 2016, dan anggarannya bersumber dari dana desa atau APBDes tahun 2016. Hingga saat ini, desa adat tetap terlibat dalam pengelolaan daya tarik wisata bersama Pokdarwis Desa Kerta. Desa Adat Kerta juga terlibat dalam pembangunan Desa Kerta dengan menyediakan lahan milik desa adat untuk dikelola menjadi fasilitas sport centre seluas 36 are. Gagasan pembangunan sport center ini telah disepakati melalui musyawarah desa pada tahun 2017. Saat ini fasilitas olahraga yang telah selesai dibangun adalah 2 unit lapangan futsal. Anggaran pembangunan fasilitas tersebut bersumber dari dana desa atau APBDes. Berdasarkan pernyataan I Kadek Januwiata selaku Manajer BUMDes Kerta Sedana, sejak dibuka pada Bulan Oktober 2019, pengunjung sport center ini telah mencapai 10.139 orang atau mencapai 403 tim. Menurut Peraturan Kepala Desa Kerta, sistem pembagian hasil kerja sama adalah 40\% masuk ke pengelola untuk biaya operasional, 30\% masuk ke desa dinas, dan 30\% masuk ke desa adat.

Secara teknis, pelaksanaan operasional unit desa wisata dilakukan oleh Kelompok Sadar Wisata (Pokdarwis) Desa Kerta yang merupakan perwakilan dari masyarakat secara keseluruhan baik masyarakat desa dinas maupun krama desa adat 
dalam mengelola aktivitas pariwisata. Selain berpartisipasi dalam pengelolaan kepariwisataan, Pokdarwis Desa Kerta juga berperan sebagai akselerator yang menjadi penghubung antar pemangku kepentingan (stakeholder) untuk membantu proses pengembangan kepariwisataan di Desa Kerta. Lebih lanjut, peran Pokdarwis Desa Kerta dalam pengembangan desa wisata yaitu untuk meningkatkan pengetahuan, wawasan, dan keterampilan para anggota masyarakat dalam bidang kepariwisataan. Sebagai lembaga penggerak pariwisata, Pokdarwis memiliki tanggung jawab untuk meningkatkan kemampuan dalam pengetahuan, skill, dan attitude para anggota Pokdarwis Desa Kerta dan masyarakat dalam bidang kepariwisataan melalui berbagai kegiatan pelatihan, sosialisasi, penyuluhan Sadar Wisata dan Sapta Pesona yang diselenggarakan oleh Pemerintah Desa, Pemerintah Daerah Gianyar, Perguruan Tinggi, serta instansi lainnya.

\section{d. Peran Pemerintah}

Peran pemerintah dalam pengembangan desa wisata Kerta yaitu sebagai regulator, salah satu implementasi untuk meningkatkan peran dan partisipasi masyarakat dalam pengembangan desa wisata, Pemerintah Desa Kerta membentuk kelompok masyarakat yang berperan sebagai penggerak dalam upaya meningkatkan kesiapan dan kepedulian masyarakat di Desa Kerta. Upaya tersebut diwujudkan pemerintah desa melalui pembentukan Kelompok Sadar Wisata (Pokdarwis) melalui Surat Keputusan Nomor 35 Tahun 2017 Tentang Kelompok Sadar Wisata. Dibentuknya Pokdarwis ini agar masyarakat sadar dan dapat berkontribusi secara aktif dalam pengembangan kepariwisataan di Desa Kerta.

Selain itu, pemerintah juga berperan sebagai fasilitator, yaitu memfasilitasi segala kebutuhan desa wisata dengan menyediakan infrastruktur baik sarana maupun prasarana dan memperluas berbagai bentuk fasilitas pariwisata di Desa Wisata Kerta. Untuk mengembangkan berbagai potensi desa termasuk potensi pariwisata, pemerintah desa dan pemerintah daerah telah membangun infrastruktur 
jalan yang memadai menuju Desa Wisata Kerta melalui program-program yang sudah direalisasikan, antara lain Program Agropolitan, Program Pengembangan Infrastruktur Perdesaan, pembangunan jalan produksi dan program-program pemberdayaan lainnya. Pemerintah juga mengupayakan pemerataan akses penerangan, akses air bersih serta jaringan telekomunikasi di seluruh Desa Kerta. Bentuk peran pemerintah lainnya dalam memfasilitasi pengembangan pariwisata di Desa Kerta yaitu melalui dukungan pemberdayaan terhadap masyarakat, yaitu dengan memberikan bimbingan teknis, pelatihan dan pembinaan kepada masyarakat dan pengelola desa wisata guna meningkatkan kualitas sumber daya manusia pariwisata di Desa Kerta, baik dari aspek wawasan, pengetahuan, serta keterampilan sumber daya manusia. Pelatihan-pelatihan tersebut seperti pelatihan tata kelola homestay berbasis masyarakat, pelatihan pengelolaan website desa, pelatihan pemandu wisata lokal, dan lainnya.

Pemerintah juga melakukan promosi desa wisata sebagai salah satu kunci penting dalam meningkatkan jumlah kunjungan wisatawan. Dalam mempromosikan kepariwisataan Desa Wisata Kerta, Dinas Pariwisata Kabupaten Gianyar memanfaatkan media sosial sebagai media promosi, seperti Facebook dan Instagram dari Dinas Pariwisata Kabupaten Gianyar dengan memuat foto-foto beserta penjelasan terkait kepariwisataan di Desa Wisata Kerta. Hal yang sama juga dilakukan oleh pemerintah desa yang memanfaatkan media sosial serta website desa untuk memuat informasi, kegiatan serta berita-berita mengenai kepariwisataan di Desa Kerta sebagai media promosi yang lebih dapat menjangkau masyarakat luas.

\section{e. Peran Media}

Dalam proses pengembangan Desa Wisata Kerta, media berperan sebagai expander yang berperan dalam mendukung publikasi dalam promosi Desa Wisata Kerta. Hingga saat ini, unsur media yang terlibat dalam pengembangan kepariwisataan yang ada di Desa Wisata Kerta yaitu Startup Go Destination Village 
(Godevi). Desa Wisata Kerta membangun kerja sama dengan Startup Godevi yang merupakan aplikasi bisnis yang dimaksudkan untuk memberdayakan desa-desa wisata. Aplikasi Godevi memiliki tujuan untuk memasarkan paket-paket desa wisata melalui konsep sustainability, empowerment, entrepreneurship (SEE). Dalam pengembangan kepariwisataan di Desa Kerta, Godevi berperan dalam pengemasan dan pemasaran paket wisata Desa Kerta melalui aplikasi serta website resminya.

\section{Tantangan dan Kendala}

Dalam upaya pengembangan Desa Wisata Kerta, masing-masing stakeholder telah menjalankan perannya sehingga dapat menunjang terwujudnya kepariwisataan di Desa Kerta. Dengan adanya keterlibatan stakeholder dari berbagai unsur menjadikan Desa Wisata Kerta semakin berkembang dengan baik dilihat dari adanya peningkatan jumlah kunjungan wisatawan serta terealisasinya pembangunan-pembangunan yang bersifat fisik maupun non fisik di Desa Wisata. Namun berdasarkan hasil penelitian di lapangan, masih ditemukan beberapa kendala terkait tidak maksimalnya peran stakeholder dalam pengembangan desa wisata.

Dari unsur perguruan tinggi belum mampu melakukan pendampingan secara berkelanjutan terhadap Desa Wisata Kerta. Kegiatan pelatihan serta pembinaan hanya dilakukan sesekali tanpa adanya tidak lanjut yang jelas mengenai agenda-agenda kedepannya sehingga belum mampu mendorong desa untuk berkembang secara optimal. Selain itu, lemahnya koordinasi pihak desa atau pengelola dengan pihak perguruan tinggi menyebabkan pelatihan dan pembinaan yang diberikan perguruan tinggi tidak sesuai dengan potensi dan kebutuhan desa wisata, sehingga pelatihan yang diberikan belum tentu dapat direalisasikan pada pengelolaan desa wisata tersebut.

Adanya keterbatasan anggaran dari pemerintah daerah juga turut menjadi kendala dalam pengembangan desa wisata. Pengadaan fasilitas penunjang pariwisata yang merupakan salah satu komponen wajib daerah tujuan wisata, namun tidak 
dapat dianggarkan secara berkesinambungan oleh pemerintah daerah. Luasnya wilayah dan terbatasnya anggaran dari APBD berakibat pada pengajuan perbaikan fasilitas yang diusulkan oleh pihak desa tidak dapat didanai oleh pemerintah daerah. Sedangkan di satu sisi, untuk dapat berjalan desa wisata dari sisi aksesibilitas maupun fasilitas harus terpenuhi. Keterbatasan alokasi dan pemanfaatan anggaran berimplikasi terhadap kurang memadainya sarana dan prasarana pariwisata serta infrastruktur penunjang kepariwisataan di Desa Wisata Kerta. Kondisi tersebut juga berpengaruh terhadap kegiatan promosi yang dilakukan, dimana masih terbatasnya fasilitas penunjang menyebabkan ketidaksiapan pengelola dalam menerima wisatawan dalam jumlah besar karena dikhawatirkan nantinya dapat menciptakan citra negatif desa wisata di mata wisatawan yang berkunjung.

Keterlibatan dari pihak bisnis dalam penyediaan barang dan jasa di Desa Wisata Kerta juga masih tergolong rendah, sehingga belum mampu menunjang kebutuhan akomodasi di Desa Kerta. Mengingat keberadaan fasilitas akomodasi sangatlah dibutuhkan dalam menunjang kegiatan pariwisata di daerah tujuan. Adanya akomodasi sangat penting sebagai pendukung kegiatan wisata para wisatawan saat berkunjung ke Desa Wisata Kerta. Dengan adanya sarana akomodasi yang memadai, tentu akan memberikan sebuah kenyamanan dan kemudahan bagi wisatawan yang datang dari luar daerah, karena bisa memanfaatkan fasilitas tersebut.

Lebih lanjut, pengembangan kegiatan pariwisata di Desa Kerta belum mampu mendorong masyarakat lokal untuk memanfaatkan peluang usaha khususnya dalam menyediakan jasa akomodasi berbasis masyarakat. Hal tersebut sangat disayangkan karena peluang yang dimiliki masyarakat lokal selaku pemilik potensi belum dapat dimanfaatkan secara optimal, sehingga belum mampu memberikan dampak ekonomi yang signifikan bagi masyarakat lokal. Adanya desa wisata seharusnya mampu menjadi peluang bagi masyarakat lokal untuk membangun usaha-usaha ekonomi sehingga mampu memberikan penghasilan tambahan bagi masyarakat. 
Selain itu, masih rendahnya tingkat partisipasi sumber daya manusia yang tergabung dalam Pokdarwis Desa Kerta juga menjadi sebuah hambatan. Karena murni dibentuk atas kesadaran, kemauan dan swadaya dari masyarakat menyebabkan kinerja lembaga internal tersebut belum berpengaruh signifikan terhadap pengembangan Desa Wisata Kerta. Sebagian masyarakat lebih memilih bekerja secara mandiri daripada ikut serta dalam kegiatan organisasi yang dirasa tidak memiliki dampak secara ekonomis, padahal kelompok tersebut diharapkan mampu secara strategis mengusahakan hak dan kepentingan masyarakat Desa Kerta khususnya dalam pengembangan kepariwisataan.

Terakhir, keterlibatan media sebagai sarana promosi desa wisata masih sangat minim. Hingga saat ini, Pemerintah Desa Kerta belum melibatkan media massa sebagai salah satu partner kerja sama secara resmi. Citra sebuah daerah dapat terbentuk dari sekumpulan keyakinan, ide dan impresi yang didapatkan seseorang mengenai daerah tersebut, sehingga keterlibatan media dapat memberikan pengaruh yang signifikan dalam membentuk citra Desa Wisata Kerta di mata khalayak nantinya.

\section{Model Kerja Sama dalam Pengembangan Desa Wisata Kerta}

Berdasarkan hasil penelitian, terdapat lima stakeholder yang terlibat dalam pengembangan Desa Wisata Kerta, yaitu perguruan tinggi, bisnis, pemerintah, komunitas dan media. Dimana kelima unsur tersebut mempunyai peran dan fungsinya masing-masing sehingga apabila digabungkan dalam suatu kolaborasi dengan tujuan tertentu maka akan memperoleh hasil yang maksimal. Masing-masing stakeholder memiliki pengaruh yang strategis dalam penyelenggaraan pariwisata di Desa Kerta. Dari kemampuan dan keterbatasan yang dimiliki masing-masing stakeholder tersebut, maka dimungkinkan untuk melakukan kerja sama agar terjadi sinergitas antar kelima pilar tersebut guna mempercepat pengembangan Desa Wisata Kerta. Oleh karena itu, diperlukan model yang relevan dan adaptif dalam upaya 
mengembangkan kepariwisataan sesuai dengan peran dan pengaruh stakeholder. Model dapat dilihat sebagai tolok ukur atau acuan dalam pengembangan desa wisata. Berikut merupakan rancangan model kerja sama dalam pengembangan Desa Wisata Kerta dapat dicermati pada Gambar 3.

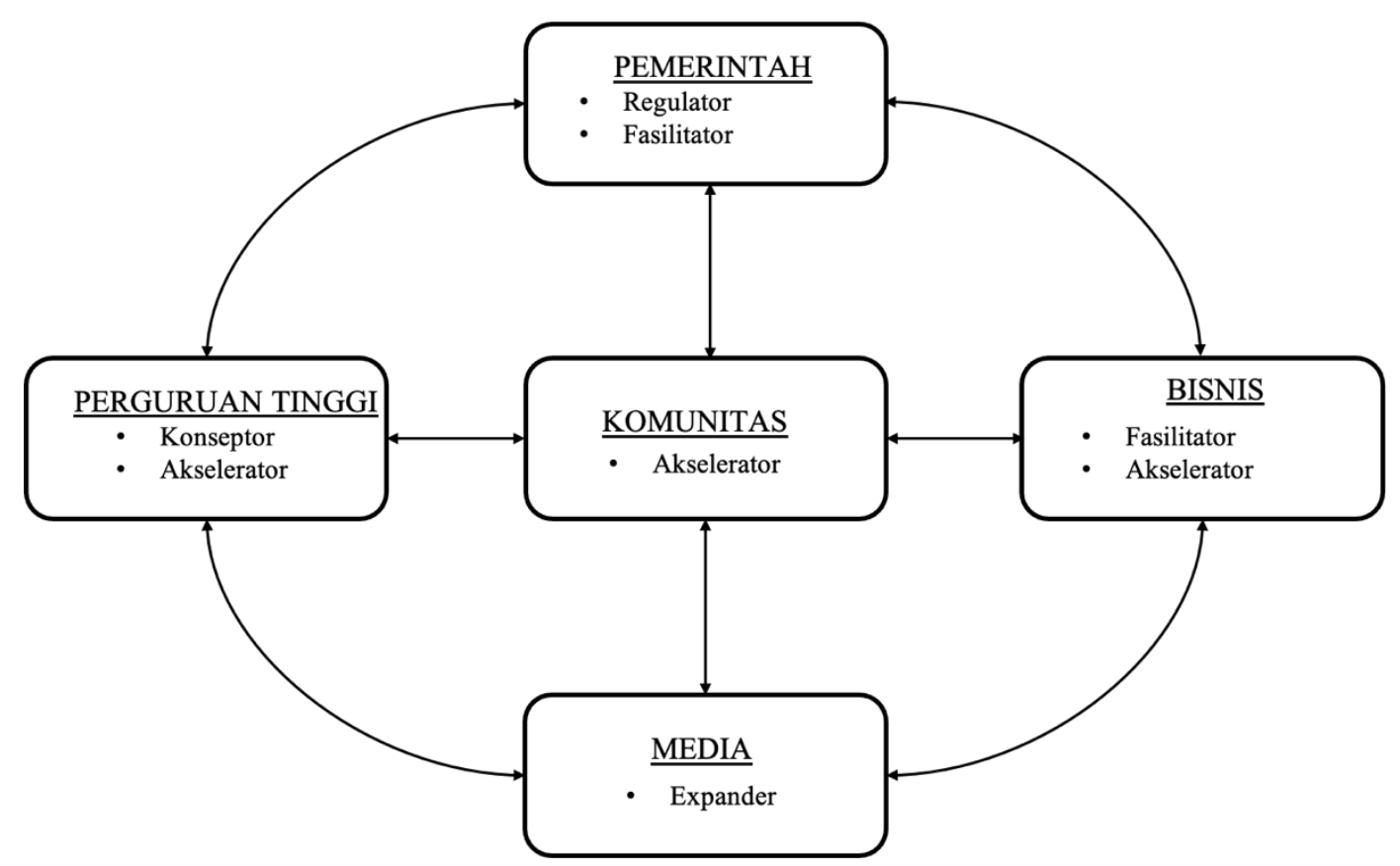

Gambar 3. Skema Model Kerja Sama dalam Pengembangan Desa Wisata Kerta Sumber: Hasil Olah Data, 2021

Berdasarkan rancangan model pada Gambar 3 diatas memperlihatkan bahwa posisi komunitas berada di tengah selaku fokus dari model kerja sama stakeholder. Hal tersebut dikarenakan komunitas yang dalam hal ini merupakan masyarakat lokal memiliki peranan penting sebagai penggerak utama kegiatan desa wisata. Oleh karena itu, segala bentuk pengembangan pariwisata harus melibatkan masyarakat dalam pengambilan keputusan karena masyarakat merupakan pemilik sumber daya serta keunikan tradisi dan budaya yang terdapat di Desa Wisata Kerta. Sumber daya yang dimaksud mencakup sumber daya alam, sumber daya manusia, dan budaya sebagai suatu kesatuan yang bersifat integral dari desa itu sendiri. Namun, keterbatasan-keterbatasan yang dimiliki unsur masyarakat mengenai informasi, sumber daya, dan kekuatan dalam pengambilan keputusan terkait upaya 
pengembangan Desa Wisata Kerta ditengahi dengan membangun kerja sama dengan stakeholder lain yang meliputi pemerintah, perguruan tinggi, bisnis, dan media selaku aktor pendukung (supporting actors) dalam mengembangkan segala potensi yang terdapat di Desa Wisata Kerta.

Sebagai unsur penggerak utama kegiatan desa wisata, Desa Kerta dalam pengembangannya menjadikan desa adat sebagai salah satu unsur masyarakat yang terlibat aktif dalam kegiatan pariwisata di daerah tersebut. Pihak desa adat menjalin kerja sama dengan desa dinas dalam menyediakan lahan milik adat untuk dikelola menjadi daya tarik wisata serta terlibat langsung dalam pengelolaan daya tarik tersebut. Adanya dualisme desa dalam pengelolaan aset khususnya desa wisata dapat menjadi sebuah landasan kuat dan sangat potensial dalam pembangunan serta pengembangan pariwisata di Desa Wisata Kerta. Hal tersebut dikarenakan desa adat memiliki aset atau potensi di bidang budaya, satu kesatuan tradisi dan tata krama, adat istiadat, dan dasar hukum yang jelas serta memiliki awig-awig (aturan adat) yang berfungsi sebagai pedoman sekaligus alat kontrol sosial bagi tata kehidupan anggotanya, yaitu krama (masyarakat) desa serta bentuk perlindungan terhadap nilainilai sosial budaya masyarakat setempat dari pengaruh budaya asing. Maka dari itu, keberadaan desa adat sangat penting dalam menunjang kepariwisataan di Desa Kerta karena memiliki kekuatan adat yang mampu mengatur masyarakatnya, sehingga desa adat dapat diyakini mampu melestarikan dan mempertahankan budaya serta adat istiadat di wilayahnya.

Sebagai unsur penggerak utama desa wisata, desa adat dan desa dinas harus mampu menguatkan koordinasi dan komunikasi yang baik untuk membangun kerja sama yang saling menguntungkan dan harmonis dalam pembangunan desa, salah satunya pembangunan pariwisata di Desa Kerta. Koordinasi antar kedua desa mutlak diperlukan dari tahap perencanaan hingga pembagian hasil dari kegiatan pariwisata. Dimana ada tahap awal perencanaan terkait penyelenggaraan pariwisata, harus terdapat perjanjian kerja sama yang jelas meliputi landasan hukum, tugas pokok dan 
fungsi, pelaksana operasional, aturan pembagian hasil dan lainnya sehingga tidak menimbulkan konflik di masa mendatang.

Dalam skema model tersebut, pemerintah memiliki peranan strategis dalam mendukung pengembangan desa wisata karena memiliki pengaruh kuat dan kewenangan legal dalam hal pengambilan keputusan dan penentu kebijakan terkait pengembangan desa wisata. Sebagai regulator, pemerintah dapat merumuskan kebijakan dan perencanaan yang sistematis dalam memetakan kebutuhan masyarakat terkait upaya pengembangan Desa Wisata Kerta. Mengingat masih terbatasnya fasilitas penunjang pariwisata di Desa Wisata Kerta, pemerintah diharapkan dapat menjadi inisiator dalam menjalin hubungan kerja sama yang kolaboratif dengan pihak swasta serta memberikan kemudahan regulasi terkait izin usaha bagi pihak swasta di Desa Wisata Kerta. Namun, peran dan fungsi pemerintah daerah sebagai controller harus diterapkan dalam kondisi tersebut, dengan tujuan mengontrol pelaksanaan pembangunan di Desa Wisata Kerta. Sebagaimana diketahui, dengan adanya keterlibatan pihak swasta yang lebih berorientasi pada keuntungan merupakan konsekuensi dalam pembangunan. Agar tidak merugikan keberadaan masyarakat lokal dan kelestarian alam di Desa Wisata Kerta, pemerintah dapat membatasi keterlibatan swasta melalui kebijakan dan regulasi. Selain itu, pemerintah harus mampu menumbuhkan semangat kewirausahaan kepada masyarakat Desa Kerta terkait penyediaan barang atau jasa bagi wisatawan, seperti penyediaan homestay berbasis masyarakat lokal, usaha rumah makan, serta jasa pemandu wisata lokal sehingga memberikan kesempatan kepada masyarakat setempat untuk mendapatkan penghasilan tambahan melalui pariwisata sekaligus dapat memberikan pengalaman autentik kepada wisatawan yang berkunjung.

Selanjutnya, perguruan tinggi merupakan stakeholder yang berperan sebagai konseptor dapat membantu pemerintah dalam mengkaji kebijakan dan perencanaan yang komprehensif terkait pengembangan Desa Wisata Kerta yang ditinjau dari berbagai aspek. Dengan keilmuan yang dimiliki, perguruan tinggi dapat menjadi 
penasehat bagi pemerintah daerah maupun Pemerintah Desa Kerta terkait pandangan dan analisis yang tepat guna memajukan Desa Wisata Kerta melalui berbagai penelitian, analisis, serta pengembangan sumber daya manusia. Untuk menyesuaikan permasalahan serta kebutuhan desa wisata, nantinya perguruan tinggi yang terlibat dalam pengembangan Desa Wisata Kerta dapat membentuk sebuah forum khusus sebagai wadah titik temu berbagai gagasan terkait permasalahan dan kebutuhan Desa Wisata Kerta. Pelatihan atau pendampingan yang dilakukan nantinya akan disesuaikan dengan potensi serta kebutuhan desa yang sebelumnya telah dikoordinasikan dengan pihak pemerintah desa maupun pengelola Desa Wisata Kerta, sehingga keilmuan yang diberikan dapat membantu pengembangan desa wisata.

Dari unsur bisnis memiliki keterlibatan dalam mendukung pengembangan Desa Wisata Kerta yaitu dalam memberikan pelatihan kepada pengelola desa wisata, memasarkan paket wisata Desa Kerta, serta menyediakan sarana pendukung pariwisata, khususnya di bidang usaha akomodasi di Desa Wisata Kerta. Mengacu pada permasalahan yang terjadi di lapangan, pengadaan fasilitas penunjang pariwisata yang merupakan salah satu komponen wajib daerah tujuan wisata, tidak dapat dianggarkan secara berkesinambungan karena adanya keterbatasan anggaran dari pihak pemerintah daerah. Dengan keterbatasan yang dimiliki, pemerintah dapat melakukan kolaborasi dengan pihak bisnis untuk pengadaan fasilitas penunjang pariwisata seperti rest area, akomodasi, rumah makan, serta fasilitas lainnya. Dengan adanya kerja sama dengan pihak swasta, tentu dapat memberi kontribusi pada pengembangan desa wisata, mengingat masih terbatasnya keberadaan fasilitas pariwisata di Desa Wisata Kerta. Selain itu, adanya fasilitas yang dibangun oleh pihak swasta dapat meningkatkan pendapatan asli daerah melalui pembayaran pajak dan retribusi, serta akan berdampak terhadap penyerapan tenaga kerja lokal. Disamping itu, unsur swasta dapat membantu Pokdarwis dalam berinovasi menciptakan paket wisata yang menarik dengan memanfaatkan potensi khas dari Desa Kerta. Hal 
tersebut dikarenakan pihak swasta mengetahui perkembangan orientasi wisatawan yang selalu berubah-ubah, sehingga stakeholder ini dapat bersinergi dalam melakukan penyusunan paket wisata yang menarik, memiliki daya saing, layak jual dan sesuai dengan segmen pasar wisatawan yang ingin disasar.

Keterlibatan unsur media yang berperan sebagai expander dalam pengembangan desa wisata juga sangat penting. Godevi selaku partner dari Desa Wisata Kerta yang berperan dalam melakukan promosi dan pemasaran paket wisata Desa Kerta, lebih lanjut dapat meningkatkan koordinasi dengan pihak pengelola desa wisata terkait upaya promosi Desa Wisata Kerta. Kedepannya pengelola desa wisata dapat meningkatkan koordinasi dengan Godevi dalam mempromosikan desa wisata dengan berinovasi merancang video promosi mengenai Desa Wisata Kerta untuk menarik minat wisatawan terhadap Desa Wisata Kerta melalui tayangan video yang menampilkan visual yang atraktif serta informatif, sehingga keragaman potensi dan aktivitas di Desa Wisata Kerta dapat diketahui masyarakat luas. Namun, perlu ditambahkan bahwa hingga saat ini upaya promosi Desa Wisata Kerta masih terbatas, belum ada tindakan promosi yang melibatkan media massa sebagai media promosi desa wisata, sehingga keterlibatan dari media massa diperlukan untuk membentuk brand image atau citra Desa Wisata Kerta. Dengan adanya keterlibatan media massa nantinya akan dapat menyebarluaskan informasi terkait kepariwisataan di Desa Kerta dan secara tidak langsung pihak media telah mempromosikan keberadaan Desa Wisata Kerta kepada khalayak umum. Dengan demikian, promosi Desa Wisata Kerta tidak hanya memanfaatkan media sosial dan brosur sebagai sarana promosi, namun juga ditingkatkan melalui kerja sama dengan pihak media massa agar masyarakat luas mengetahui keberadaan Desa Wisata Kerta dan tertarik untuk berkunjung ke desa wisata tersebut. 


\section{Simpulan dan Saran}

Seluruh unsur stakeholder telah menjalankan peran masing-masing dalam pengembangan desa wisata, namun keterlibatan dari pihak bisnis dalam penyediaan barang dan jasa serta keterlibatan unsur media masih tergolong rendah dalam pengembangan Desa Wisata Kerta. Model kerja sama stakeholder dalam pengembangan Desa Wisata Kerta menempatkan komunitas atau masyarakat lokal sebagai sentral karena merupakan penggerak utama kegiatan desa wisata. Segala bentuk pengembangan pariwisata harus mempertimbangkan masyarakat untuk ikut terlibat dalam pengambilan keputusan karena masyarakat merupakan pemilik sumber daya serta keunikan tradisi dan budaya yang terdapat di desa wisata, selanjutnya didorong oleh keterlibatan stakeholder lain yang meliputi pemerintah, perguruan tinggi, bisnis, dan media selaku stakeholder pendukung.

Saran yang dapat diberikan antara lain, 1) Pemerintah diharapkan mampu menjadi inisiator dalam membangun kemitraan dengan pihak swasta yang sudah melakukan pembangunan atraksi maupun akomodasi di Desa Wisata Kerta, serta melibatkan media massa secara resmi sebagai salah satu partner resmi dalam mengembangkan desa wisata untuk menyebarluaskan informasi positif terkait kepariwisataan di Desa Kerta dan secara tidak langsung dapat mempromosikan keberadaan Desa Wisata Kerta kepada khalayak umum. 2) Keberadaan Pokdarwis perlu terus didukung dan dibina sehingga dapat berperan lebih efektif dalam menggerakkan partisipasi masyarakat untuk mewujudkan kegiatan kepariwisataan di Desa Kerta. 3) Diharapkan adanya pembinaan dan pendampingan secara berkesinambungan dari pemerintah daerah, perguruan tinggi dan pihak swasta dalam pengembangan Desa Wisata Kerta agar segala potensi dan sumber daya yang dimiliki Desa Kerta dapat dikelola secara maksimal. 


\section{Ucapan Terima Kasih}

Terima kasih yang sebesar-besarnya penulis ucapkan kepada Dr. Ir. I Gusti Ayu Oka Suryawardani, M.Mgt., Ph.D selaku Koordinator Program Studi Magister Pariwisata atas kesempatan yang diberikan kepada penulis untuk menjadi karyasiswa pada Program Magister pada Program Pascasarjana Universitas Udayana. Dr. I Nyoman Sukma Arida, M.Si. selaku Pembimbing I dan Bapak Gde Indra Bhaskara, M.Sc., Ph.D. selaku Pembimbing II yang telah dengan penuh kesabaran, ketulusan dan penuh dedikasi sebagai seorang akademisi, telah memberikan segala kemampuan dalam membimbing penulis selama menyelesaikan studi dan penelitian tesis ini. Para dosen penguji, yaitu Dr. Drs. I Nyoman Sunarta, M.Si., Dr. I Wayan Suardana, SST.Par., M.Par. dan Dr. I Nyoman Sudiarta, SE., M.Par. yang telah memberikan banyak masukan, saran dan koreksi untuk menyempurnakan tesis ini.

\section{Daftar Pustaka}

Budiamanta, A.A. 2008. Corporate Social Responsibility Alternatif Bagi Pembangunan Indonesia. Jakarta: Indonesia Center for Sustainability Development.

Donaldson, T. dan Preston, L. 1995. The Stakeholder Theory of the Corporation: Concepts, Evidence, and Implications. Academy of Management Review, 65-91.

Soemaryani, I. 2016. Pentahelix Model to Increase Tourist Visit to Bandung and Its Surrounding Areas Through Huan Resource Development. Academy of Strategic Management Journal, Vol. 15, Special Issues 3, 2016.

Undang-Undang Republik Indonesia Nomor 6 Tahun 2014 Tentang Desa. 


\section{Profil Penulis}

Ni Putu Tiya Paristha lahir di Gianyar pada tanggal 29 September 1997. Penulis menyelesaikan Pendidikan Strata-1 (S1) dengan Program Studi Sastra Inggris pada tahun 2019 di Fakultas Ilmu Budaya, Universitas Udayana. Kemudian melanjutkan pendidikan ke jenjang Strata-2 (S2) dengan Program Studi Magister Pariwisata di Fakultas Pariwisata, Universitas Udayana pada tahun 2019-2021.

Dr. I Nyoman Sukma Arida, M.Si merupakan seorang dosen tetap di Fakultas Pariwisata, Universitas Udayana. Beliau menyelesaikan Pendidikan S1 di Fakultas Geografi, Universitas Gadjah Mada pada tahun 2000. Kemudian menempuh Pendidikan S2 di Universitas Udayana dengan mengambil Program Studi Magister Ilmu Lingkungan dan menyelesaikan Pendidikan S3 di Program Studi Pariwisata, Universitas Gadjah Mada pada tahun 2015. Bidang keahlian yang ditekuni yaitu meliputi Ekowisata, Pariwisata Berbasis Masyarakat (Community-Based Tourism), serta Wisata Perdesaan. Selain aktif mengajar, beliau juga aktif dalam mengembangkan kerja sama pengabdian fakultas dengan beberapa instansi dan dinas pemerintah, diantaranya Dinas Pariwisata Kabupaten Gianyar, Dinas Pariwisata Kabupaten Karangasem, Dinas Pariwisata Manggarai Timur, Conservation International Indonesia, dan Universitas Gadjah Mada. Terakhir, pada September tahun 2019, beliau bersama beberapa alumni Fakultas Pariwisata mendirikan sebuah marketplace yang bernama Go Destination Village (Godevi).

Gde Indra Bhaskara, M.Sc., Ph.D. merupakan seorang dosen tetap di Fakultas Pariwisata, Universitas Udayana. Pada tahun 2001, beliau menyelesaikan Pendidikan S1 di Sekolah Tinggi Pariwisata Bali. Kemudian melanjutkan Pendidikan S2 di Bournemouth University, Inggris pada tahun 2002-2004. Setelah kembali dari Inggris, beliau bekerja di sebuah perusahaan yang bernama HES Global pada kurun waktu 2004-2006. Pada periode berikutnya, beliau mengajar di Manajemen Perhotelan Indonesia (MAPINDO) selama dua tahun. Selanjutnya pada tahun 2008, beliau 
Ni Putu Tiya Paristha, I Nyoman Sukma Arida, Gde Indra Bhaskara

diterima di Universitas Udayana sebagai dosen tetap. Hanya berkesempatan mengajar selama dua semester setelah diangkat menjadi dosen tetap di Universitas Udayana, beliau mendapatkan beasiswa untuk melanjutkan Pendidikan S3 ke Bournemouth University di tahun 2010. Bidang keahlian yang ditekuni yaitu meliputi Heritage Tourism, Local Community Participation, dan Digital Tourism. 